Journal of Chemical, Biological and Physical Sciences
An International Peer Review E-3 Journal of Sciences
Available online atwww.jcbsc.org
Section B: Biological Sciences

\title{
Physicochemical properties and composition of safou (Dacryodes edulis) non-conventional oil from Côte d'Ivoire
}

\section{Beugré Romuald Léonce Kadji ${ }^{1}$, Andrée Emmanuelle Sika², Fankroma Martial Thierry Koné ${ }^{1}$, Soumailla Dabonné ${ }^{1}$}

${ }^{1}$ Laboratory of Biocatalysis and Bioprocessing, Department of Food Science and Technology, University Nangui Abrogoua, 02 BP 801 Abidjan 02, Côte d'Ivoire

${ }^{2}$ Laboratory of Biotechnology and Food Microbiology. Department of Food Science and Technology, University Nangui Abrogoua, 02 BP 801 Abidjan 02, Côte d'Ivoire

Received: 05 December 2017; Revised: 29 December 2017; Accepted: 08 January 2018

\begin{abstract}
Safou (Dacryodes edulis) is a non-conventional oleaginous fruit which is used in many West and Central Africa country. Unfortunately, this fruit grown in Côte d'Ivoire is still unknown to the public and is the subject of very few studies. This study investigated the physicochemical properties of safou oil (D. edulis) produced in Côte d'Ivoire. Oil was extracted from two varieties of Dacryodes edulis (D. edulis var edulis and D. edulis var parvicarpa) from 3 sites (CNRA-Azaguié, Azaguié-Blida and GrandMorié). Oil was studied using standard procedures. The result revealed that the colour of safou oil was yellow and the odor was agreeable. Safou oil was liquid at room temperature. Refractory value, specific gravity and viscosity ranged from 1.463 to 1.473 , 0.901 to 0.902 and 27.50 to 28.50 , respectively. Oil content, acid values, peroxide values, iodine values, saponification values and unsaponifiable matters ranged from 68.88 to $71.93 \%, 1.25$ to $1.87 \mathrm{mg} \mathrm{KOH} / \mathrm{g}, 3.48$ to $4.46 \mathrm{meq} \mathrm{O}_{2} / \mathrm{kg}, 46.80$ to $51.33 \mathrm{mg} / 100 \mathrm{~g}$, 173.16 to $215.76 \mathrm{mg} \mathrm{KOH} / \mathrm{g}$ and 0.25 to $0.30 \mathrm{~g} / \mathrm{kg}$, respectively. The fatty acid composition revealed 42.60 to $45.45 \%$ saturated, 27.44 to $28.55 \%$ monounsaturated and
\end{abstract}


20.43 to $23.27 \%$ polyunsaturated fatty acids. Safou oil was rich in palmitic acid (38.16 to $40.16 \%$ ) and oleic acid (27.44 to $28.55 \%$ ). The ratio PUFA/SFA was ranged from 0.47 to 0.51 . There were significant differences between the two safou varieties and between the tree sites. This study revealed the high potential of D. edulis (safou) oil in food and cosmetic industries.

Keywords: Dacryodes edulis, pulp oil, fatty acids, characterization, Côte d'Ivoire

\section{INTRODUCTION}

The African pear tree (Dacryodes edulis (G.Don) H.J.Lam; Burseraceae) is a tropical oleiferous fruit tree and possesses enormous potential in Africa ${ }^{1}$. Various parts of the tree are used in traditional medicine ${ }^{2-3}$. The wood serves for firewood and carpentry ${ }^{4}$. The entire tree is used in Agro-forestry systems for soil conservation, fertility, shade and apiculture ${ }^{5}$. Dacryodes edulis fruit or safou is popular in the diets of many Africans. It can be eaten raw, roasted or boiled in hot water, and is eaten alone or used in garnishing cooked or roasted maize.

During the last three decades, more and more studies have been conducted on safou (D. edulis), essentially the tree and its fruit. The scientific research on D. edulis focused on the characterization of the nutritive value of its pulp and its oil ${ }^{6}$, the oil extraction processes ${ }^{7}$ and $D$. edulis tree of propagation techniques ${ }^{8}$. These revealed excellent nutritional qualities of the fruit pulp and interesting food processing properties of the oils extracted from the pulp and kernel safou ${ }^{9}$. The pulp, the only edible part of the fruit is particularly rich in lipids, indicated that safou could be an important source of oil ${ }^{10}$. Previous study have shown that safou oil is a rich source of triglycerides with saturated fatty acid content and an unsaturated fatty acid content ${ }^{11}$. The fruits could provide vegetable oils for the food, pharmaceutical and cosmetic industries ${ }^{12-13}$.

The fatty acid composition of oil is its most useful chemical feature. Many of the chemical tests for oil identity or purity can be related to the fatty acid content of the oil ${ }^{14}$. Poly unsaturated fatty acids such as linoleic acid play an important role in modulating human metabolism and consumers consider fatty acid composition to be one of the important parameters of nutritional quality. Such fatty acids are known to be essential for human health ${ }^{15}$. The relationship between dietary fat and chronic illness including cardiovascular disease and so on is also recognized.

The exploitation on industrial scale of safou involves the determination of the physicochemical properties of the fruit and the oil it contains. If more studies have been conducted on safou oil in many West and Central Africa country, few scientific works have been published on the physicochemical characteristics of its oil in Côte d'Ivoire. This study investigated the physicochemical properties of safou oil (D. edulis) produced in Côte d'Ivoire.

\section{MATERIALS AND METHODS}

Plant material: Ripe fruits of safou (Dacryodes edulis) were collected from three localities of the Agneby region in South-East of Côte d'Ivoire (CNRA Azaguié, Azaguié-Blida and Grand-Morié). Three samples $(1 \mathrm{~kg})$ of each safou variety (D. edulis var. edulis and D. edulis var. parvicarpa) were collected from each site. A total of 18 samples were subjected to this study. For each collection, the safou were 
harvested at maturity from trees, and packaged in bags in nets. They were immediately transported to the laboratory for the realization of different analyzes.

Sample preparation: The ripe fruits of each variety from safou (D. edulis) were thoroughly washed with distilled water and split open with a sharp knife to remove the seed from the pulp. Then the pulp obtained was ground into flour using a blender. The ground material obtained was used to perform chemical analyzes.

Oil extraction and physicochemical analysis: Safou pulp oils were extracted by Soxhlet using hexan as solvent ${ }^{16}$. The oils were then analyzed for specific gravity ${ }^{17}$, refractive index ${ }^{18}$ and viscosity using Brookfield viscometer. The colour, odor and state of oil at room temperature were observed by visual and olfactory inspection. Standards ISO were used to determine the peroxide value ${ }^{19}$, acid value ${ }^{20}$, iodine value $^{21}$, saponification value ${ }^{22}$ and unsaponifiable matters ${ }^{23}$.

Fatty acid analysis: The fatty acid composition was determined according to the method of Li et al. ${ }^{24}$. Fatty acids were transformed into their methyl esters (FAME) through transmethylation ${ }^{25}$. FAME was analyzed using gas chromatography (GC) on HP-5890 system (Agilent Technologies, Palo Alto, CA, USA), equipped with a flame ionization detector (FID) and a fused silica capillary column HP-5 (30 m $\times$ $0.32 \mathrm{~mm} \times 0.25 \mu \mathrm{m}$ film thickness). Column temperatures were programmed from 150 to $280{ }^{\circ} \mathrm{C}$ with a rise of $3{ }^{\circ} \mathrm{C} / \mathrm{min}$. Both the temperatures of detector and injector were $250{ }^{\circ} \mathrm{C}$. Nitrogen gas at a flow rate of $1.5 \mathrm{~mL} / \mathrm{min}$ was used as the mobile phase. One (1) $\mu \mathrm{L}$ of the fully saponified oil was injected in split mode using a 1/50 split ratio. The unknown FAME were identified by comparing their retention times with those of pure standards and quantified on the basis of peak areas. The fatty acid composition was expressed as relative percentage of the total peak area.

Statistical analysis: All analyses reported in this study were carried out in triplicate. Mean value and standard deviation were calculated. Data were assessed by Analysis of Variance (ANOVA) and Duncan Multiple Range analysis ( $\mathrm{p}=0.05$ ), with the software Statistica 7.1 (Stat Soft Inc, Tulsa USA Headquarters).

\section{RESULTS AND DISCUSION}

Physical composition of safou pulp oil: The physical properties of the studied safou oil are shown in Table 1. Results showed that there is no significant $(\mathrm{p}=0.05)$ difference for most physical properties.

In this study, oil content of safou pulp ranged between 68.88 to $71.93 \%$. Determination of oil content in plants is important because it predicts the profitability of given plants as potential source of oil. High oil content in plant seed/fruit implies that processing it for oil will be economical ${ }^{26}$. Dacryodes edulis var edulis from Azaguié-Blida and Dacryodes edulis var parvicarpa from CNRA Azaguié have significantly higher oil content $(71.93 \%)$ and refractory value (1.473) than other oil samples, respectively. The oil yield of Ivorian safou is appreciable, higher than Cameroon safou pulp oil (33-65\%) ${ }^{27}$ and than most of the conventional oilseeds such as cotton $(15-27 \%)^{28}$, soybean $(14 \%)$ and palm fruit $(20 \%)^{29}$. Previous studies have showed that the oil content of safou pulp ranged between 30 to $60 \%$, allowing it to be classified as an oil fruit ${ }^{11-30-32}$. Dacryodes edulis var. edulis from Azaguié-Blida have significantly higher oil content than other oil samples studied. Previous studies suggested that the variations between oil yields could be attributed to some factors such as the origin, ripening stage, harvesting time of fruits ${ }^{33-34}$ and the extraction method employed ${ }^{35-36}$. 
Table 1: Physical composition of safou pulp oil from Côte d'Ivoire

\begin{tabular}{|c|c|c|c|c|c|c|}
\hline \multirow{2}{*}{ Parameter } & \multicolumn{2}{|c|}{ CNRA Azaguié } & \multicolumn{2}{|c|}{ Azaguié-Blida } & \multicolumn{2}{|c|}{ Grand Morié } \\
\hline & Var parvicarpa & Var edulis & Var parvicarpa & Var edulis & Var parvicarpa & Var edulis \\
\hline Oil content $(\%)$ & $69.00 \pm 0.66^{\mathrm{a}}$ & $68.88 \pm 1.57^{\mathrm{a}}$ & $68.50 \pm 0.50^{\mathrm{a}}$ & $71.93 \pm 0.41^{\mathrm{b}}$ & $69.20 \pm 0.74^{\mathrm{a}}$ & $70.07 \pm 1.50^{\mathrm{a}}$ \\
\hline Refractory value (at $25^{\circ} \mathrm{C}$ ) & $1.473 \pm 0.003^{\mathrm{b}}$ & $1.464 \pm 0.001^{\mathrm{a}}$ & $1.464 \pm 0.001^{\mathrm{a}}$ & $1.465 \pm 0.001^{\mathrm{a}}$ & $1.463 \pm 0.001^{\mathrm{a}}$ & $1.465 \pm 0.003^{\mathrm{a}}$ \\
\hline Specific gravity (at $25^{\circ} \mathrm{C}$ ) & $0.902 \pm 0.001^{\mathrm{a}}$ & $0.902 \pm 0.001^{\mathrm{a}}$ & $0.901 \pm 0.001^{\mathrm{a}}$ & $0.902 \pm 0.002^{\mathrm{a}}$ & $0.902 \pm 0.001^{\mathrm{a}}$ & $0.901 \pm 0.001^{\mathrm{a}}$ \\
\hline Viscosity & $28.33 \pm 0.29^{\mathrm{a}}$ & $28.00 \pm 0.50^{\mathrm{a}}$ & $28.17 \pm 0.29^{\mathrm{a}}$ & $28.33 \pm 0.76^{\mathrm{a}}$ & $27.50 \pm 0.50^{\mathrm{a}}$ & $28.50 \pm 1.32^{\mathrm{a}}$ \\
\hline Colour & \multicolumn{6}{|c|}{ Yellow } \\
\hline Odor & \multicolumn{6}{|c|}{ Agreeable } \\
\hline Oil state (at room temperature) & \multicolumn{6}{|c|}{ Fluid } \\
\hline
\end{tabular}

$*$ Values given are mean \pm standard deviation of triplicate determination. Means with different letters within the same row denote significant differences among cultivars $(\mathrm{p}=0.05)$. Var parvicarpa $=$ Dacryodes edulis var parvicarpa $;$ Var edulis $=$ Dacryodes edulis var edulis 
Indeed, using chloroform to extract the pulp oil, Ikhuoria and Maliki ${ }^{26}$ reported $23.3 \%$ yield. Moreover, Akpabio et al. ${ }^{37}$ using petroleum ether $\left(60-80^{\circ} \mathrm{C}\right)$ reported $56.5 \%$ yield. According to Kinkela et al. ${ }^{38}$, pulp oil yields could reach $70 \%$ in rare cases.

Refractive index of safou oil ranged from 1.463 to 1.473 . This indicates that the Ivorian safou oil could be recommended for food industry because it is comparable in thickness to most drying oils have refractive index between 1.48 and $1.49^{39}$. According to Pearson ${ }^{40}$, the amount of impurities that are contained in the oil affects the degree of reflection caused by a ray of light during refractive index determination of the oil.

The odor in safou oil samples is agreeable. This means that they all have no offensive smell. At $25^{\circ} \mathrm{C}$ the colour of all safou oil samples is yellow and their viscosity varies between 27.50 and 28.50 , indicating rather fluid oils. The determination of oil colour provides information on the pigments which may probably exist in an oil. This suggests that in addition to chlorophyll, oils are rich in carotenoid pigments and xanthophylls ${ }^{41}$. Colour and viscosity are the most common physical parameters used to evaluate the extent of frying oil deterioration in commercial and household frying ${ }^{42}$.

The oil extracted from Ivorian safou pulp is fluid at room temperature, meaning that it could be considered as oil. According to Erasmus ${ }^{43}$, safou oil would be suitable for body massage because it remains liquid at room temperature.

The specific gravity of safou pulp oil at $25^{\circ} \mathrm{C}$, ranged from 0.901 to 0.902 and is similar to those reported for most conventional oilseeds which are about $0.9^{44}$. Specific gravity of an oil gives information on its purity and depends on some factors such as the oil chemical composition and the temperature. According to Paul and Palmer ${ }^{45}$, the specific gravity of different refining oils varies with their molecular weights which are affected by refining process involved.

Chemical composition of safou pulp oil: The chemical properties of the studied safou oil are presented in Table 2 and show that the geographical localization has an influence on safou parameters and fatty acid composition in the same region. Variations according the cultivar were also observed ${ }^{7}$. This may be due to ecological factors affecting seeds/fruits in different geographical locations.

Iodine values give information on the degree of unsaturation in oil and it is an identity characteristic of native oil. It indicates the degree of unsaturation in the fatty acids of triacylglycerol. This value could be used to quantify the amount of double bonds present in the oil, which reflects the susceptibility of oil to oxidation. The higher the iodine index, the more unsaturated the oil. In the present study, the iodine values of safou oil ranged from $46.80 \mathrm{~g} / 100 \mathrm{~g}$ (D. edulis var parvicarpa of CNRA Azaguié) to 51.33 $\mathrm{g} / 100 \mathrm{~g}$ (D. edulis var edulis from Grand-morié). These low values obtained show that safou oil is saturated oil and non-siccative ${ }^{46}$. This non-drying attribute qualified this oil for use in paint industry ${ }^{47}$. According to Amoo et al. ${ }^{48}$, the iodine value is also an index for assessing the oil ability to go rancid. Our results are near to those of African pear D. edulis (59.6) ${ }^{11}$, palm oil (50-55) ${ }^{44}$ and avocado pear (44.07) ${ }^{26}$. These values were lower than those reported by Kapseu and Parmentier ${ }^{49}$ and Dzondo-Cadet et al. ${ }^{30}$ for safou pulp oil (85 and 79.6, respectively) and those of unsaturated fatty acid-rich oils such as cottonseed (100-123), sunflower (118-141) and soybean (124-139) ${ }^{44}$.

Peroxide value measures the quantity of hydroperoxides in oil; it is used as an indicator of deterioration or rancidity of oils. The lower the peroxide value, the better the quality of the oil. The oil from $D$. edulis var edulis from Grand-morié showed the lowest peroxide value $\left(3.48 \mathrm{meq} \mathrm{O}_{2} / \mathrm{kg}\right)$ and D. edulis var parvicarpa from Azaguié-Blida showed the highest value (4.46 meq $\left.\mathrm{O}_{2} / \mathrm{kg}\right)$.

172 J. Chem. Bio. Phy. Sci. Sec. B, November 2017 - January 2018; Vol.8 No.1; 168-179. [DOI:10.24214/jcbps.B.8.1.16879. 
Table 2: Chemical composition of safou pulp oil from Côte d'Ivoire

\begin{tabular}{|c|c|c|c|c|c|c|}
\hline \multirow{2}{*}{ Parameter } & \multicolumn{2}{|c|}{ CNRA Azaguié } & \multicolumn{2}{|c|}{ Azaguié-Blida } & \multicolumn{2}{|c|}{ Grand-Morié } \\
\hline & Var parvicarpa & Var edulis & Var parvicarpa & Var edulis & Var parvicarpa & Var edulis \\
\hline Acid value (mg KOH/g) & $1.40 \pm 0.03^{\mathrm{ab}}$ & $1.25 \pm 0.12^{\mathrm{b}}$ & $1.37 \pm 0.18^{\mathrm{ab}}$ & $1.87 \pm 0.29^{c}$ & $1.73 \pm 0.17^{\mathrm{ac}}$ & $1.77 \pm 0.32^{\mathrm{ac}}$ \\
\hline Peroxide value (meq $\mathrm{O}_{2} / \mathrm{kg}$ ) & $4.08 \pm 0.32^{\mathrm{ab}}$ & $3.57 \pm 0.50^{\mathrm{a}}$ & $4.46 \pm 0.56^{\mathrm{b}}$ & $3.96 \pm 0.15^{\mathrm{ab}}$ & $3.88 \pm 0.12^{\mathrm{ab}}$ & $3.48 \pm 0.45^{\mathrm{a}}$ \\
\hline Iodine value $(\mathrm{g} / 100 \mathrm{~g})$ & $46.80 \pm 0.20^{\mathrm{a}}$ & $49.05 \pm 0.21^{\mathrm{ab}}$ & $48.13 \pm 2.65^{\mathrm{ab}}$ & $49.63 \pm 2.50^{\mathrm{ab}}$ & $47.59 \pm 1.88^{\mathrm{a}}$ & $51.33 \pm 1.53^{\mathrm{b}}$ \\
\hline Saponification value $(\mathrm{mg} \mathrm{KOH} / \mathrm{g}$ ) & $173.16 \pm 3.17^{\mathrm{a}}$ & $213.9 \pm 0.70^{\mathrm{b}}$ & $185.33 \pm 7.76^{\mathrm{c}}$ & $206.36 \pm 0.90^{\mathrm{d}}$ & $173.66 \pm 4.93^{\mathrm{a}}$ & $215.76 \pm 1.33^{b}$ \\
\hline Unsaponificable matter (g/kg) & $0.25 \pm 0.07^{\mathrm{a}}$ & $0.26 \pm 0.02^{\mathrm{a}}$ & $0.26 \pm 0.03^{\mathrm{a}}$ & $0.26 \pm 0.04^{\mathrm{a}}$ & $0.28 \pm 0.03^{\text {bc }}$ & $0.30 \pm 0.02^{\mathrm{c}}$ \\
\hline
\end{tabular}

* Values given are mean \pm standard deviation of triplicate determination. Means with different letters within the same row denote significant differences among cultivars $(\mathrm{p}=0.05)$. Var parvicarpa $=$ Dacryodes edulis var parvicarpa $;$ Var edulis = Dacryodes edulis var edulis 
The possibility of using safou oil in food industry is also linked to its relatively low peroxide values, which is less than 10 meq $\mathrm{O}_{2} / \mathrm{kg}^{44}$. According to Mutinsumu et al. ${ }^{50}$, the low peroxide value is a characteristic of saturated fatty acids. In the study of Ajayi and Odesanwo ${ }^{14}$, a high peroxide value was reported in safou oil from $21.23 \mathrm{meq} \mathrm{O}_{2} / \mathrm{kg}$. However, Ugbogu et al. ${ }^{51}$ showed that peroxide value between 20 and 40 results to rancid taste. This suggests that safou oil can be stored for long period without deterioration.

Saponification value is used in checking alduteration ${ }^{52}$. The high saponification values suggest the possibility of industrial applications for foods (table or cooking oils). Some authors successfully replaced margarine by safou pulp to obtain nutritious biscuits ${ }^{13}$. Saponification values of Ivorian safou oil (173.16 to $215.16 \mathrm{mg} \mathrm{KOH} / \mathrm{g}$ ) compare favorably with usual oils such as cotton oil (189-198), peanut oil (187196) and soybean oil (189-195) $)^{44}$. So, safou oil does not need hydrogenation to optimize saponifying character. It can be used for the manufacture of soap or shampoo in cosmetics industry ${ }^{51}$. According to Mampouya et $a .^{53}$, saponification value varies inversely with the molecular weight of fatty acid constituting the triglyceride. It informs about the length of a fatty acid chain. Since the saponification values measured are close to $200 \mathrm{mg} \mathrm{KOH} / \mathrm{g}$, most fatty acids composing the triglycerides of safou oil are of C18. Our results are close to those found in Nigerian safou oils (191.1-201.4 mg KOH/g $)^{11-52}$.

The unsaponifiable matter of Ivorian safou pulp oil was ranged from $0.25 \mathrm{~g} / \mathrm{kg}$ (D. edulis var parvicarpa from CNRA Azaguié) to $0.30 \mathrm{~g} / \mathrm{kg}$ (D. edulis var edulis from Grand-morié). This value is similar to that obtained for palm kernel oil $(0.22 \%)^{49}$ and lower than those reported for other potential cosmetic oils such as cotton seed oil $(0.52 \%)$ and peanut oil $(0.33 \%)$.

Table 2 also show that Dacryodes edulis var edulis from Azaguié-Blida and D. edulis var edulis from CNRA Azaguié have significantly higher $(1.87 \mathrm{mg} \mathrm{KOH} / \mathrm{g})$ and lower $(1.25 \mathrm{mg} \mathrm{KOH} / \mathrm{g})$ acid values than all oil samples, respectively. Acid values are very important parameters because they measure the amount of free fatty acid (FFA), which has a direct relationship with the quality of oil. High acid value is an indication that the oil was not adequately conserved. Acid value and FFA determine the use of oil for either edible or industrial utility. Acid value of the oil suitable for edible purpose should not exceed $4 \mathrm{mg}$ $\mathrm{KOH} / \mathrm{g}^{35-54}$. The low safou oil acidity obtained in this study indicates it good stability during storage and that this oil can be considered as fit for use as edible oil ${ }^{54}$.

Fatty acid profile of safou pulp oil: Safou oils are rich in saturated fatty acid (SFA) followed by monounsaturated (MUFA) and polyunsaturated (PUFA) fatty acids (Table 3, Figure 1). The prominent class of fatty acid (FA) was represented by saturated fatty acid (SFA) with 42.60 to $45.45 \%$. Palmitic acid (38.16 to $40.16 \%$ ) was the predominant SFA followed by stearic acid (3.67 to 5.64\%) and myristic acid ( 0.10 to $0.77 \%$ ). Palmitic acid was also found to be the major FA from safou oil. Results showed that $D$. edulis var parvicarpa from Azaguié-Blida displayed the highest palmitic acid value $(40.16 \%)$ whereas $D$. edulis var edulis from CNRA Azaguié the lowest (38.16\%).

The second class of FA was the monounsaturated fatty acid (MUFA) with 27.44 to $28.55 \%$, followed by polyunsaturated fatty acid (PUFA) with 20.43 to $23.27 \%$. Oleic acid was found to be the predominant unsaturated fatty acid. Dacryodes edulis var parvicarpa from Azaguié-Blida and D. edulis var edulis of CNRA Azaguié have significantly lower and higher oleic acid contents, respectively. Results also showed that PUFA was constituted with linoleic acid (18.12 to $21.92 \%)$ and linolenic acid (1.33 to $2.32 \%$ ). 
Table 3: Fatty acid content of safou pulp oil from Côte d'Ivoire

\begin{tabular}{lcccccc}
\hline \multirow{2}{*}{ Fatty acid (\%) } & \multicolumn{2}{c}{ CNRA Azaguié } & \multicolumn{2}{c}{ Azaguié-Blida } & \multicolumn{2}{c}{ Grand-Morié } \\
& Var parvicarpa & Var edulis & Var parvicarpa & Var edulis & Var parvicarpa & Var edulis \\
\hline Myristic (C14:0) & $0.76 \pm 0.01^{\mathrm{c}}$ & $0.77 \pm 0.01^{\mathrm{c}}$ & $0.10 \pm 0.00^{\mathrm{a}}$ & $0.10 \pm 0.00^{\mathrm{a}}$ & $0.25 \pm 0.07^{\mathrm{b}}$ & $0.30 \pm 0.00^{\mathrm{b}}$ \\
Palmitic (C16:0) & $38.16 \pm 0.56^{\mathrm{c}}$ & $38.76 \pm 0.01^{\mathrm{bc}}$ & $40.16 \pm 0.08^{\mathrm{a}}$ & $39.72 \pm 0.54^{\mathrm{a}}$ & $39.47 \pm 0.01^{\mathrm{ab}}$ & $39.45 \pm 0.04^{\mathrm{ab}}$ \\
Stearic (C18:0) & $3.67 \pm 0.01^{\mathrm{a}}$ & $3.67 \pm 0.01^{\mathrm{a}}$ & $5.18 \pm 0.06^{\mathrm{b}}$ & $5.24 \pm 0.01^{\mathrm{b}}$ & $5.63 \pm 0.01^{\mathrm{c}}$ & $5.64 \pm 0.01^{\mathrm{c}}$ \\
Oleic (C18:1) & $28.50 \pm 0.14^{\mathrm{c}}$ & $28.55 \pm 0.07^{\mathrm{c}}$ & $27.44 \pm 0.01^{\mathrm{a}}$ & $27.47 \pm 0.06^{\mathrm{a}}$ & $28.32 \pm 0.01^{\mathrm{b}}$ & $28.30 \pm 0.01^{\mathrm{b}}$ \\
Linoleic (C18:2) & $18.22 \pm 0.03^{\mathrm{a}}$ & $18.12 \pm 0.18^{\mathrm{a}}$ & $19.44 \pm 0.01^{\mathrm{b}}$ & $19.05 \pm 0.56^{\mathrm{b}}$ & $21.92 \pm 0.01^{\mathrm{c}}$ & $21.92 \pm 0.01^{\mathrm{c}}$ \\
Linolenic (C18:3) & $2.32 \pm 0.04^{\mathrm{a}}$ & $2.31 \pm 0.03^{\mathrm{a}}$ & $2.10 \pm 0.00^{\mathrm{b}}$ & $2.15 \pm 0.07^{\mathrm{b}}$ & $1.35 \pm 0.00^{\mathrm{c}}$ & $1.33 \pm 0.02^{\mathrm{c}}$ \\
$\sum$ SFA & $42.60 \pm 0.56^{\mathrm{a}}$ & $43.20 \pm 0.01^{\mathrm{a}}$ & $45.45 \pm 0.01^{\mathrm{b}}$ & $45.06 \pm 0.53^{\mathrm{b}}$ & $45.36 \pm 0.06^{\mathrm{b}}$ & $45.38 \pm 0.05^{\mathrm{b}}$ \\
$\sum$ MUFA & $28.50 \pm 0.14^{\mathrm{a}}$ & $28.55 \pm 0.07^{\mathrm{a}}$ & $27.44 \pm 0.01^{\mathrm{b}}$ & $27.47 \pm 0.06^{\mathrm{b}}$ & $28.32 \pm 0.01^{\mathrm{c}}$ & $28.30 \pm 0.01^{\mathrm{c}}$ \\
$\sum$ PUFA & $20.54 \pm 0.01^{\mathrm{a}}$ & $20.43 \pm 0.15^{\mathrm{a}}$ & $21.54 \pm 0.01^{\mathrm{b}}$ & $21.20 \pm 0.49^{\mathrm{b}}$ & $23.27 \pm 0.01^{\mathrm{c}}$ & $23.26 \pm 0.03^{\mathrm{c}}$ \\
PUFA/SFA & 0.48 & 0.47 & 0.47 & 0.47 & 0.51 & 0.51 \\
\hline
\end{tabular}

*Values given are mean \pm standard deviation of triplicate determination. Means with different letters within the same row denote significant differences among cultivars ( $\mathrm{p}=0.05)$. Var parvicarpa = Dacryodes edulis var parvicarpa; Var edulis = Dacryodes edulis var edulis; SFA = Saturated fatty acids; MUFA = Mono-unsaturated Fatty Acid; PUFA = Polyunsaturated fatty acid. 


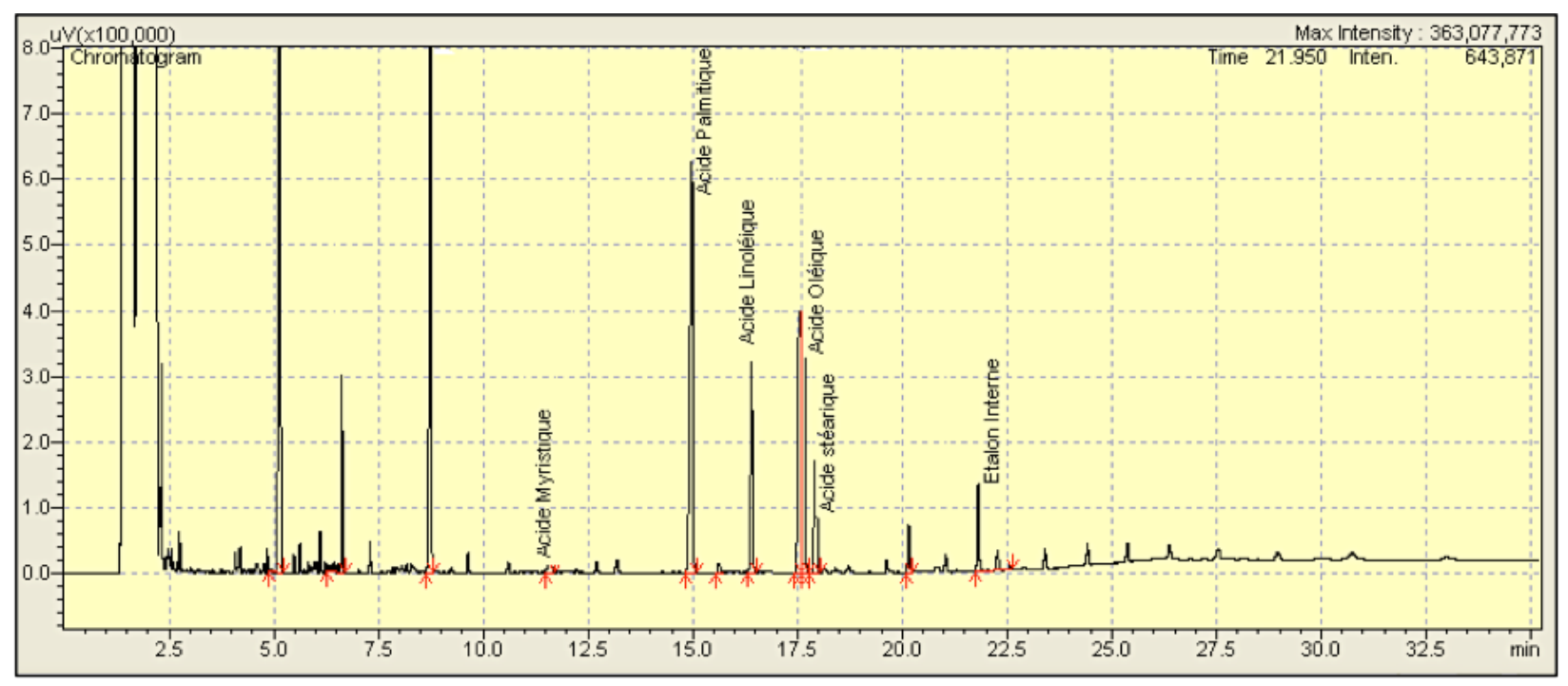

Figure 1: Gas chromatography of fatty acids from safou pulp oil from Côte d'Ivoire

Safou pulp oil can be used for frying or spreading pastry production. Mutinsumu et al. ${ }^{50}$ established a correlation between fatty acids and blood cholesterol. It related that blood cholesterol values have an incidence on cardiovascular diseases. It was shown that SFA are able to induce an increase of cholesterolemy, whereas MUFA and PUFA, such as vegetable oil reduce $\mathrm{it}^{50}$. According to the equilibrium of fatty acid composition, Ivorian safou oil has a good PUFA/SFA ratio ranged from 0.47 to 0.51 . These results are in agreement with those found by Dzondo-Cadet et $a l .{ }^{30}$. Safou oil could be a promising solution for cold use or cooking with essential fatty acids guaranteed. The safou oil importance in the composition of breast milk was reported by Rocquelin et al. ${ }^{55}$. Indeed, Congolese women take in their food a large amount of fruits whose safou. It was shown that the DHA (docosahexaenoic acid) percentage found in the maternal milk were very close to the amount of PUFA in safou ${ }^{56}$. The fatty acid composition is therefore suitable for breast fed infant development. The ratio PUFA/SFA of safou pulp oil from Côte d'Ivoire (0.47-0.51) was in agreement with those from Nigeria (0.34) and Cameroon $(0.61)^{30}$.

Palmitic acid (C16:0) with 38.16 to $40.16 \%$ was the predominant fatty acid followed by oleic acid (C18:1) being 27.44 to $28.55 \%$ and linoleic acid (C18:2) with 18.12 to $21.92 \%$. Similar profiles were previously reported in safou oils where palmitic, oleic and linoleic acids constituted approximately $90 \%$ of the total fatty acid composition ${ }^{36-57}$.

Oleic $(\omega 9)$ and linoleic $(\omega 6)$ acids are known for their anti-inflammatory properties. Oleic acid is reputed for its role in preservation of cardiovascular diseases and its nutritional value. Linoleic acid had favorable nutritional implications and beneficial physiological effects in the prevention of coronary heart disease and cancer $^{58}$. According to Ha et al..$^{59}$, linoleic acid has been reported to have diverse biological effects such as increasing atherosclerotic risk and increasing body fat.

Results also showed that Ivorian safou oil contain two essential fatty acids, namely linoleic ( $\omega 6)$ and linolenic ( $\omega 3)$ acids. The human body is not able to synthesize these fatty acids. Therefore, they must be provided in the diet, hence they are classified as essential fatty acids ${ }^{14}$. So, the presence of two of the 
essential fatty acids in the safou oil makes them to be nutritionally valuable. According to Dzondo-Cadet et al. ${ }^{30}$, safou oil could become a good producer of $\omega 3$ in the world since it contains 1.33 to $2.32 \%$ of linolenic acid.

\section{CONCLUSION}

This study has shown that Dacryodes edulis (safou) is a good source of lipids so can be used as an alternative resource base for fats and oils. Ivorian safou oil is palmito-oleo-linoleic type, which could substitute or complete conventional oils such as palm oil. Use of this oil in African countries could be of high benefit for health, for adults and even for infants. Such study suggests some industrial applications in food and cosmetics industry. In a further work, we will try to complete this research by exploring triacylglycerol and phenol composition.

\section{REFERENCES}

1. J. Kengué, Le Safoutier (Dacryodes edulis (G.Don) H.J.Lam), premières données sur la morphologie et la biologie. Thèse de doctorat, Université de Yaoundé, Cameroun, 1990.

2. J. Okafor, Int. Tree Crops J., 1983, 2, 255.

3. D. Majesty, C. Amadi, E. A. Ugbogu, E. Adindu, B. Amadi, Asian J. Plant Sci. Res., 2012, 2(4), 437.

4. O. Ndoye, M. R. Pérez, A. Eyebe, The markets of non-timber forest products in the humid forest zone of Cameroon. London, UK: Overseas Development Institute, 1997.

5. V. Ndangang, A survey of traditional agro-forestry woody plants of the North-West province of Cameroon. Pre-optional study report, National Advance School, Agriculture, Yaounde, Cameroon, 1989, 72.

6. I. A. Ajayi, R. A. Oderinde, D. O. Kajogbola, J. I. Uponi, Food Chem., 2006, 99(1), 115.

7. C. Kapseu, Oléagineux, Corps gras, Lipides, 2009, 16, 215.

8. J. Kengué, Fruits for the future 3. Safou: Dacryodes edulis. Research for Development in Department for International Development, 2002, 147.

9. R. N. Poligui, I. Mouaragadja, É. Haubruge, F. Francis, Biotechnol. Agron. Soc. Envir., 2013, 17(1), 131.

10. A. Ondo-Azi, M. Ella Missang, T. Silou, J. Chalchat, Variation in physicochemical characteristics of safou (Dacryodes edulis (G. Don) H.J. Lam) fruits. International conference, nutrition and food production in the congo basin. Brussels, Belgium. 30 September - 1 October, 2013.

11. U. Omoti, D. A. Okiy, J. Sci. Food Agric., 1987, 38, 67.

12. C. Kapseu, E. Avouampo, B. Djeumako, For. Trees Livelihoods, 2002, 12(1-2), 97.

13. C. Mbofung, T. Silou, I. Mouragadja, For. Trees Livelihoods, 2002, 12(1-2), 105.

14. I. Ajayi, O. Adesanwo, World J. Agric. Sci., 2009, 5(3), 279.

15. C. M. Mbofung, J. M. Gee, D. J. Knight, J. Sci. Food Agric., 1994, 66(2), 213.

16. AOAC, Official Methods of Analysis.15th Edition, Association of Official Analytical Chemistry, Washington DC, 1990. 
17. ISO6883, Animal and vegetable fats and oils. Determination of conventional mass per volume (litre weight in air). International Organization of Standardization, 2007.

18. ISO6320, Animal and vegetable fats and oils. Determination of refractive index. International Organization of Standardization, 2000.

19. ISO3960, Animal and vegetable fats and oils. Determination of peroxide value-Iodometric (visual) endpoint determination. International Organization of Standardization, 2007.

20. ISO660, Animal and vegetable fats and oils. Determination of acid value and acidity. International Organization of Standardization, 2009.

21. ISO3961, Animal and vegetable fats and oils. Determination of iodine value. International Organization of Standardization, 2009.

22. ISO3657, Animal and vegetable fats and oils. Determination of saponification value. International Organization of Standardization, 2003.

23. ISO3596, Animal and vegetable fats and oils. Determination of unsaponifiable matter-Method using diethyl ether extraction. International Organization of Standardization, 2000.

24. R. Li, Q. Xia, M. Tang, S. Zhao, W. Chen, X. Lei, X. Bai, Afr. J. Biotechnol., 2012, 11(39), 9377.

25. ISO5509, Animal and vegetable fats and oils. Preparation of methyl esters of fatty acids. International Organization of Standardization, 2000.

26. E. Ikhuoria, M. Maliki, Afr. J. Biotechnol., 2007, 6(7), 950.

27. S. A. Ndindeng, Z. Ambang, N. Woin, F. A. Ngome, S. A. Njebu, D. Mapiemfu-Lamaré, W. N. Leke, J. M. A. Etoa, G. L. Chi, V. T. Mbah, Front. Sci., 2012, 2(6), 250.

28. B. A. Orhevba, A. N. Efomah, Int. J. Basic Appl. Sci., 2012, 1, 398.

29. J. M. Nzikou, M. Mvoula-Tsieri, L. Matos, E. Matouba, A. C. Ngakegni-Limbili, M. Linder, S. Desobry, J. Appl. Sci., 2007, 7, 1107.

30. M. Dzondo-Gadet, J. M. Nzikou, E. Matouba, A. Etoumongo, M. Linder, S. Desobry, Process Biochem., 2005, 40(1), 307.

31. T. Silou, G. Rocquelin, G. Gallon, T. Molagui, Riv. Ital. Sostanze Gr., 2000, 77(2), 85.

32. T. Silou, Oilseeds \& fats Crops and Lipids, 2014, $21(2), 1$.

33. M. K. Egbekun, M. U. Ehieze, Plant Foods Hum. Nutr., 1997, 51(1), 35.

34. J. Bezard, T. Silou, S. Kiakouama, G. Sempore, Rev. Fr. Corps Gras, 1991, 7/8, 233.

35. S. E. G. Ekissi, F. M. T. Koné, P. K. B. Koffi, L. P. Kouame, Int. J. Biosci., 2016, 8(5), 190.

36. V. E. Tshiombe, N. Masimango, T. Silou, A. Samia, D. Nsimba, Int. J. Agric. Food Sci., 2014, $4(1), 46$.

37. U. Akpabio, I. Akpan, I. E. Matthew, A. U. Akpan, World J. Appl. Sci. Technol., 2011, 3(2), 27.

38. T. Kinkéla, R. Kama-Niamayoua, D. Mampouya, T. Silou, Afr. J. Biotechnol., 2006, 5(12)

39. O. M. Oluba, O. Adeyemi, G. C. Ojieh, I. O. Isiosio, Int. J. Cardiovasc. Res., 2008, 5(2), 814.

40. D. Pearson, The chemical analysis of foods.7th Edition. Church Livingstone Longman group limited, 1991.

41. A. Karleskind, Manuel des corps gras. Tome II. Tec. and Doc. Edition. Paris, 1992.

178 J. Chem. Bio. Phy. Sci. Sec. B, November 2017 - January 2018; Vol.8 No.1; 168-179. [DOI:10.24214/jcbps.B.8.1.16879. 
42. S. M. Abdulkarim, K. Long, O. M. Lai, S. K. S. Muhammad, H. M. Ghazali, Food Chem., 2007, 105(4), 1382.

43. U. Erasmus, Fats that heal fat that hill. A live Books, Canada, 1993.

44. Codex Alimentarius, Graisses et huiles végétales, division II version abrégée FAO/WHO. Codex Stan 1993.20-1981; 23-1981, 1993.

45. P. C. Paul, H. H. Palmer, Food Theory and Applications. John Wiley Palmer, HH, Sons Incorporated, New York, 1972.

46. K. A. Hunter, L. C. Crosbie, A. Weir, G. J. Miller, A. K. Dutta-Roy, J. Nutr. Biochem., 2000, 11(7), 408.

47. E. N. Onyeike, G. N. Acheru, Food Chem., 2002, 77(4), 431.

48. I. Amoo, A. Eleyinmi, N. Ilelaboye, S. Akoja, J. Food Agric. Environ., 2004, 2, 38.

49. C. Kapseu, M. Parmentier, Sciences des Aliments (France), 1997, 17, 325.

50. M. Mutinsumu, K. Taba, T. Silou, M. Tshiombe, M. Buluma, Int. J. Agric. Food Sci., 2015, 5(1), 21.

51. A. E. Ugbogu, E. I. Akubugwo, F. O. Uhegbu, C. G. Chinyere, O. C. Ugbogu, K. A. Oduse, Int. J. Biosci., 2013, 3, 125.

52. I. Akubugwo, A. Ugbogu, Pak. J. Nutr, 2007, 6(1), 75.

53. D. Mampouya, R. K. Niamayoua, S. Goteni, A. N. Loumouamou, T. Kinkela, T. Silou, Adv. J. Food Sci. Technol., 2013, 53(3), 230.

54. O. E. Peace, A. O. Aladesanmi, Pakistan J. Nutr., 2008, 7, 292.

55. G. Rocquelin, S. Tapsoba, F. Mbemba, G. Gallon, C. Picq, Int. J. Food Sci. Nutr., 1998, 49(5), 343.

56. G. Rocquelin, S. Tapsoba, M.-C. Dop, F. Mbemba, P. Traissac, Y. Martin-Prével, Eur. J. Clin. Nutr., 1998, 52(3), 164.

57. A. S. Ondo-Azi, C. E. Missang, T. Silou, For. Trees Livelihoods, 2009, 19(2), 99.

58. B. D. Oomah, S. Ladet, D. V. Godfrey, J. Liang, B. Girard, Food Chem., 2000, 69(2), 187.

59. Y. L. Ha, N. K. Grimm, M. W. Pariza, J. Agric. Food Chem., 1989, 37(1), 75.

\section{* Corresponding author: Fankroma Martial Thierry Koné}

Department of Food Science and Technology, University Nangui Abrogoua, 02 BP 801 Abidjan 02, Côte d'Ivoire

Online Publication Date: 08.01.2018 